\title{
SMES (SOMETHING MORE FOR EVERY ONE)
}

\author{
Geetha Rajaram* \& Sreeveena**
}

\section{ABSTRACT}

"Good things in Life begin small......SMEs (Something More for
Everyone)"
The small businesses in India are big nowadays. The small and medium
enterprises (SME) sector in India is undergoing a 'Big Transformation'
riding on the government's recognition of its significance, in terms of
its contribution to the GDP and its huge potential for employment
generation. A significant observation indicates that during the last 14
years of a liberalized regime, the country has seen phenomenal growth
in the SME sector. Developing and venturing into the new products,
diversifying their businesses and services by adopting new fechnical
skills and thereby improving productivity has been the overall action
plan for this ever multiplying closet.
Over the years, the SSI sector in India has continued to remain an
important sector of the economy with its noteworthy contribution to
the gross domestic product, industrial production, employment
generation and exports. As per the Third All India Census of SSIs
(2001-02), there were 10.52 million SSI units in the country, of which
\%

* Geetha Rajaram Faculty Member-Finance, Mount Carmel Institute of Management Email ID-geetha_rajaram@rediffmail.com

** Sreeveena - Faculty Member-Finance, ICFAl National College, Malleswaram Email ID-salemsreeveena@rediffmail.com 
1.37 were registered and 9.15 unregistered units. For the year ended March 2004, the said number increased to 11.52 million, providing employment to 27.40 million persons and contributing an output of over Rs.3, 480 billion in FY2004.

As a result of globalization coupled with the WTO regime, Indian SMEs are beginning to show a sign of steady transformation with the industry undergoing a sweeping change in its entirety. The SME sector in India is highly hetero geneous comprising of tiny unorganized enterprises to modern and more organized factories at the higher end of the spectrum.

The rapidly increasing globalization of the Indian economy has been providing enormous opportunities for the small and medium enterprises in India to enhance their business.

This paper attempts to find how SMEs could capitalize on such opportunities and the need to grapple with fierce competitionino verseas markets increasingly, which is becoming more challenging with realignment and coming together of global markets after liberalization.

\section{Introduction}

The small businesses in India are big nowadays. The small and medium enterprises (SME) sector in India is undergoing a 'Big Transformation' riding on the government's recognition of its significance, in terms of its contribution to the GDP and its huge potential for employment generation. A significant observation indicates that during the last 14 years of a liberalized regime, the country has seen phenomenal growth in the SME sector. Developing and venturing into the new products, diversifying their businesses and services by adopting new technical skills and thereby improving productivity has been the overall action plan for this ever multiplying closet.

\subsection{Definition of SME - A relative phenomena}

There is no universal definition of small and medium enterprises. In some countries, there are certain objective standards, which classify the units as micro, small or medium enterprises depending on the number of employees. In some other countries, annual turnover of the company determines the size of an enterprise. The concept of size is also a relative phenomenon 
with reference to the local economies, since a large company in a small country could possibly be considered as a small company in a larger country.

\section{Indian SME definition - A recent origin}

In the Indian context, primarily the concept of Small Scale Industry has been in vogue and the medium enterprise definition is of more recent origin. An SSI is defined on the basis of limit of historical value of investment in plant \& machinery, which at present is upto Rs. 10 million. However, in respect of some specified items, this investment limit has been hiked to Rs. 50 million. For the recently announced Small and Medium Enterprises Fund, the Gol has approved the limit of investment in plant and machinery above Rs.10 million and upto Rs.100 million for defining a unit as a Medium Enterprise.

Amongst the developing countries, India has been the first to display special consideration to SSIs and basic focus has been to make economical use of capital and absorb the abundant labour supply in the country.

\subsection{Contribution of Indian SSIs}

Over the years, the SSI sector in India has continued to remain an important sector of the economy with its noteworthy contribution to the gross domestic product, industrial production, employment generation and exports. As per the Third All India Census of SSIs (2001-02), there were 10.52 million SSI units in the country, of which 1.37 were registered and 9.15 unregistered units. For the year ended March 2004, the said number increased to 11.52 million, providing employment to 27.40 million persons and contributing an output of over Rs.3,480 billion in FY2004.

\section{Tenth Five Year Plan}

The Tenth Five Year Plan for the Indian economy has set a target of 8 percent growth per annum in GDP and to bring down the poverty ratio to 11 percent over the next decade. The Plan has also noted that achieving and sustaining such ambitious growth targets would require adequate attention to small and medium enterprises which have great potential to offer wage employment. In order to pursue the growth with employment agenda, heavy reliance is placed on the SME sector. 


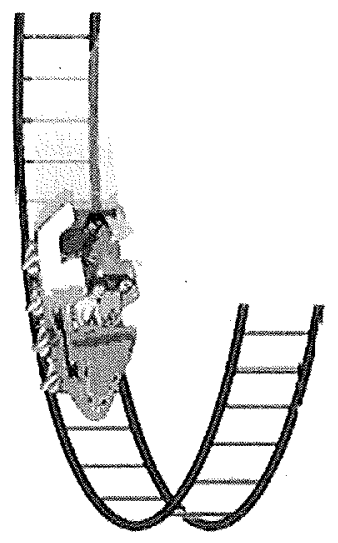

As a result of globalization coupled with the WTO regime, Indian SMEs are beginning to show a sign of steady transformation with the industry undergoing a sweeping change in its entirety. The SME sector in India is highly heterogeneous comprising of tiny unorganized enterprises to modern and more organized factories at the higher end of the spectrum. In India the small and medium enterprises are not well defined. The internal group set up by the Reserve Bank of India has recently recommended that the units with investment in plant and machinery in excess of SSI limit and upto Rs. 10 crores may be treated as medium enterprises.

According to official estimates, the small enterprise sector has attained a higher growth of about $8 \%$ per year during the last decade compared to the overall growth of $5 \%$ for the whole industrial sector. This sector is undergoing a phase of transition, shedding its old skin and emerging in the market as a dynamic and outgoing player. The realization of its power has set across the entire sector like a wild fire and the SMEs are fast becoming the centers of constant innovation.

According to a report on SME Sector, India has nearly three million SSIs which account for almost $95 \%$ of industrial units and account for almost $40 \%$ of industrial output and $42 \%$ of India's total exports quipping to be the future drivers of economic growth. The SME sector produces about 8,000 products all over the country, mainly in the hinterland, which contribute $40 \%$ of the country's industrial output and offers the largest employment after agriculture. The number of SME units has increased by about $40 \%$ since 1994. As a result of this the production has increased 
by $150 \%$, employment by over $30 \%$ and exports by around $140 \%$. The annual growth rate of SME sector exceeds the growth of the entire industrial sector. An estimated 290 lakh persons are employed in this sector. A study commissioned by the Ministry reveals that with a corresponding export activity of Rs. 78 billion was 1 crore jobs- 86 lakhs of direct employment and 14 lakhs of study further reveals that if we achieve our export target of Rs. 150 dollars, we shall add a further 1 crore jobs; $85 \%$ of it direct employment and $15 \%$ indirectly associated jobs.

\subsection{Export Performance}

SSI sector in India has been exhibiting a striking export performance. Barring few years, exports have grown double digit in the last 10 years. Exports at current prices in 2002-03, the latest year for which data is available, stood at Rs. 86000 crores. This works out to about $34 \%$ of total exports in India in the same year. Major sectors contributing to SSI exports include readymade garments $(27 \%)$, engineering goods $(14.5 \%)$, chemicals \& pharmaceuticals, electronics \& computers, and processed foods ( $11 \%$ each). In terms of export orientation, sports goods have $100 \%$ exports from SSI sector, followed by readymade garments $(90 \%)$, leather $(70 \%)$, marine products $(47 \%)$ and chemicals \& pharmaceuticals $(44 \%)$. The rapidly increasing globalization of the Indian economy has been providing enormous opportunities for the small and medium enterprises in India to enhance their business. However to capitalize on such opportunities SMEs need to grapple with fierce competition in overseas markets increasingly becoming more challenging with realignment and coming together of global markets after liberalization. Right from the early plan periods, the Government of India, RBI and commercial banks have focused on the Small scale Industries. This is also one of the reasons for the inclusion of this sector under the priority sector. 
Fig. 1

Figure showing the other reasons for inclusion of SME in the priority sector

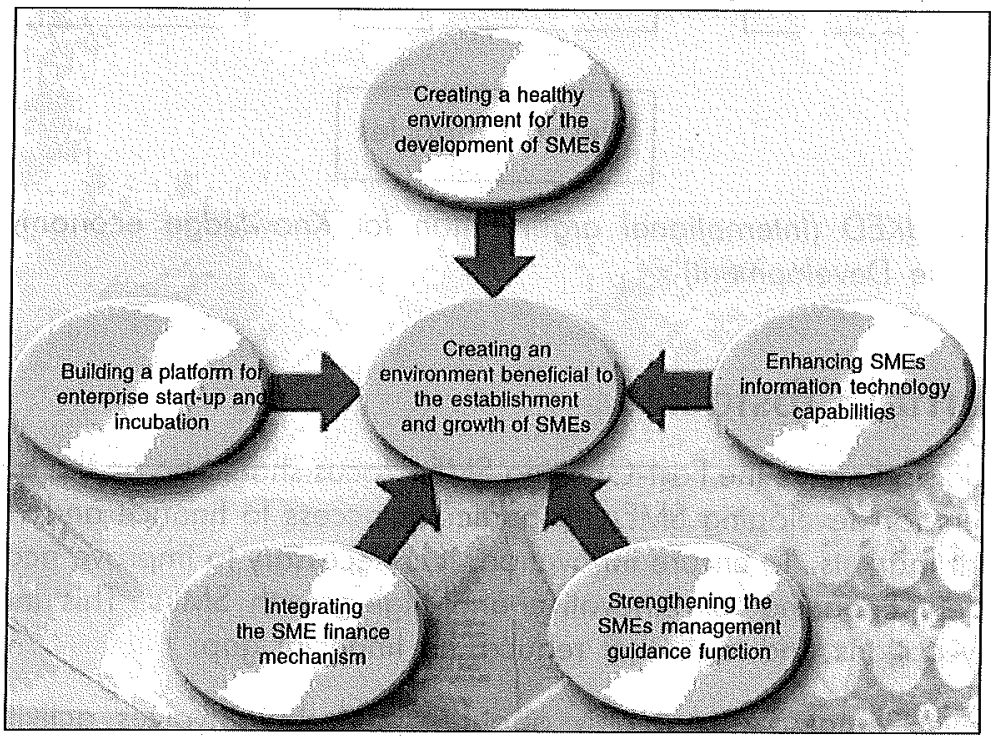

Despite their dominant numbers and importance in job creation, SMEs have traditionally faced difficulty in obtaining formal credit or equity. Maturities of commercial bank loans extended to SMEs are often limited to a period far too short to pay off any sizeable investment. Access to competitive interest rates is reserved for only a few selected blue-chip companies while loan interest rates offered to SMEs remain high. Banks in many developing countries have traditionally lent overwhelmingly to the government, which offered less risk and higher returns. 
Figure - 2

The Field of Innovation - External and Internal SME Obstacles

$$
\text { External Obstacles }
$$

Field of Innovation

Supply Side

\section{Demand Side}

Internal Obstacles

Source: IKED (International organization for Knowledge economy and enterprise Development)

\section{External Obstacles}

In order to finance the Fast-Growing SMEs, focus should be on the external barriers for developing SMEs, in particular access to finance and venture capital markets. To ensure innovation, it is necessary to improve access to sufficient financing for innovative and high-growth SMEs. This includes policy options and tools that reduce the financial gap.

However, funding is not only about capital, but involves activities to overcome agency problems in the market, establish trust and make investors more willing to take risks, encouraging, intelligent capital, are also key issues.

\section{Internal Obstacles}

Ideas on how to raise internal management skills and competencies in SMEs in global knowledge based economies, including the role of policy measures, practical tools and methods, which can support efforts in raising skills and competencies have to be addressed. This significant limited entrepreneurial activity and the low or no growth within SMEs are caused by external factors as outlined previously, as well as internal lack of sufficient skills and competencies Implementing local services is partly about the interplay between SME development programmes and initiatives carried 
out at national and local level, respectively, and partly about the interplay between public and private involvement. The extent to which such activities should be decentralised to local and private authorities/service providers depends on several factors including the competencies of these actors. There is an urgent need to strengthen multilateral dialogue and international cooperation including public-private partnership in order to develop conducive SME policies and measures and to help SMEs face the challenges of innovation, competitiveness and globalisation. Benchmarking SME policies and exchange of good and bad practices among countries/regions is one way to foster the mutual learning process, and several kinds of crossborder collaboration can be envisaged to help policymakers in planning and developing relevant and sustainable SME policy options.

\section{Financing to SME sector}

These preferences and tendencies have exacerbated the lack of financing for SMEs. Traditional commercial banks and investors have been reluctant to service SMEs for a number of reasons. They include the following:

- SMEs are regarded by creditors and investors as high-risk borrowers due to insufficient assets and low capitalization, vulnerability to market fluctuations and high mortality rates.

- Information asymmetry arising from SMEs' lack of accounting records, inadequate financial statements or business plans makes it difficult for creditors and investors to assess the credit-worthiness of potential SME proposals.

- High administrative/transaction costs of lending or investing small amounts do not make SME financing a profitable business.

\subsection{Present Scenario of SMEs in India}

As a result, commercial banks are generally biased toward large corporate borrowers, who provide better business plans, have credit ratings, more reliable financial formation, better chances of success and higher profitability for the banks. When banks do lend to SMEs, they tend to charge them a commission for assuming risk and apply tougher screening measures which drive up costs on all sides. 


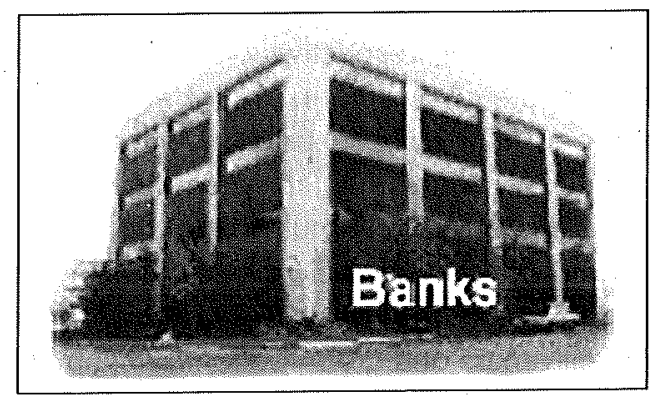

According to the Cll report, the SMEs which are debt strapped go through three stages. The first stage is the inability to meet the projections, loss of important customers, operating losses and intermittent shortage of cash. The second stage is that of persistent operating losses, need to waiver from lenders etc. The third stage the continuing operating losses, out of cash, credit situation, principal defaults and legal insolvency: According to $\mathrm{Cll}$, the operational guidelines for debt restructuring have been bifurcated into direct and indirect measures that will facilitate in re-balancing debt for medium enterprises.

The direct measures are venture financing, creation of special purpose vehicles (SPVs) for SMEs, factoring services, various schemes for bill discounting by banks and selling non-core unprofitable operations.

The indirect measures include credit rating, annual reporting be made mandatory for SMEs, increase collaborations between medium and large enterprises etc.

With the globalization and WTO guidelines on the removal of protection, the survival of SSI sector, particularly without the protections and reservations enjoyed by this sector in India came under cloud. But large manufacturers and global players have realized the strengths of the SME sector, which can be the backbone for growth, without necessitating large inventory build-up by the big corporate sector. Hence having dispelled the challenges posed by the WTO guidelines, the SME sector in India has emerged as a focus area.

Further, the large corporate houses having access to capital market as well as international funding, the credit growth for the banks from large corporate houses has become stagnant. Moreover, the spreads from lending to large corporate houses have become thin. On the contrary, the SME segments have good appetite for credit absorption and yields from the SMEs are also very encouraging for the banks. 
The public sector banks have always been supporting the SME sector with credit and other transactional services. The old private banks had a niche market for SME, based on their territory; support base and development of SME activities in their area. Banks like Karur Vysya Bank or City Union Bank in Tamilnadu or Development Credit Bank in Mumbai have supported SMEs from their area. Now, even the new private banks have realized the interest spreads available from the SMEs and have started focusing on this segment.

Government of India has announced a special policy package policy for the SMEs for stepping up credit flow to this sector. In terms of package, the public sector banks have been advised to fix their own targets for financing SMEs with the objective of doubling the credit flow to the SME sector by 2010. Besides, the government has also introduced the SME development Bill, 2005, in Parliament, which seeks to facilitate the promotion and development of SMEs and enhance their competitiveness.

The World development report 2005 indicates that small firms obtain only $19 \%$ of their financing from external sources while large firms meet up to $44 \%$ of their financing needs through external sources. This is largely due to higher costs of collecting and analyzing information concerning SMEs, high unit transactions costs associated with SME lending because of the relatively small loan sizes, exacerbated by weak or underdeveloped financial markets and policy distortions. Hence a need for public policy intervention in terms of creating conditions that will lower the costs of SME lending to financial institutions and increase their reach in providing services to SMEs.

Table 1.1

Table showing sources of finance of small and big firms

\begin{tabular}{|l|c|c|}
\hline \multicolumn{1}{|c|}{ Sources } & Big Firms & Small Firms \\
\hline Internal Sources & $52.0 \%$ & $72.0 \%$ \\
State Sources & $5.0 \%$ & $1.0 \%$ \\
Banks & $22.0 \%$ & $5.0 \%$ \\
Family \& Friends & $4.0 \%$ & $10.0 \%$ \\
Others & $12.0 \%$ & $12.0 \%$ \\
Equity & $5.0 \%$ & \\
\hline
\end{tabular}

Source: World Development Report, 2005 
Figure 1.1

Figure showing sources of finance of big firms

\section{Big Firms}

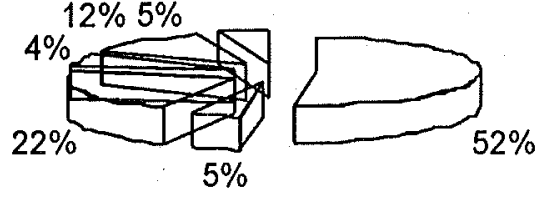

$\square$ Internal Sources

$\square$ State Sources

$\square$ Banks

$\square$ Family \& Friends

$\square$ Others

$\square$ Equity

Figure 1.2

Figure Showing Sources of Finance of Small Firms

\section{Small Firms}

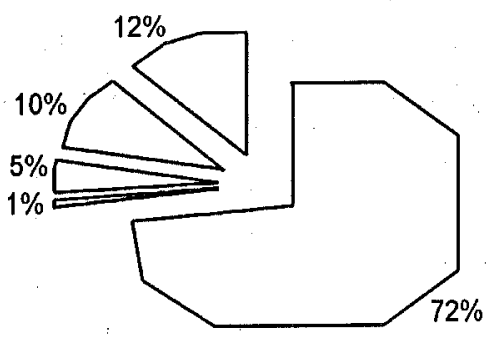

$\square$ Internal Sources

$\square$ State Sources

$\square$ Banks

$\square$ Family \& Friends

$\square$ Others 


\subsection{Challenges faced by SMEs}

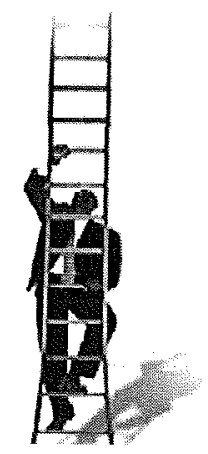

The challenges faced by the small and medium enterprises may be briefly set out as follows:

a. Small and medium enterprises (SME), particularly the tiny segment of the small enterprises, have inadequate access to finance due to lack of financial information and non-formal business practices. SMEs also lack access to private equity and venture capital and have a very limited access to secondary market instruments.

b. SMEs face fragmented markets in respect of their inputs as well as products and are vulnerable to market fluctuations.

c. SMEs lack easy inter-State or international market access.

d. The access of SMEs to technology and product innovations is also limited. There is lack of awareness of global best practices.

e. SMEs face considerable delays in the settlement of dues/payment of bills by the large buyers.

\subsection{Recent Developments}

With the deregulation of the financial sector, the ability of the banks to service the credit requirements of the SME sector depends on the underlying transaction costs, efficient recovery processes and available security. There is an immediate need for the banking sector to focus on credit and finance requirements of SMEs.

Public Sector Banks will be advised to fix their own targets for funding SMEs in order to achieve a minimum $20 \%$ year on year growth in credit 
to the SME sector. The objective is to double the flow of credit from Rs. 67,600 crore in 2004-05 to Rs. 1,35,200 crore to the SME sector by 2009-10, i.e., within a period of five years.

Various steps taken by the Gol / RBI to enhance the flow of credit to SMEs in the recent past include

(i) increase in the loan limit of composite loan scheme for SSIs upto Rs. 5 million,

(ii) providing loans to SSIs within the interest rate band of 2 percent above and below the respective bank's PLR,

(iii) setting up of Technology Bureau for Small Enterprises (TBSE) to address the technology related needs of SSls and proposal to convert TBSE into a full fledged Technology Bank,

(iv) opening of specialised SSI branches throughout the country, presently numbering 417 ,

(v) introduction of Laghu Udyami Credit Card for SME borrowers with satisfactory track record,

(vi) identification of 60 clusters for focused development by including their credit requirements in the respective State Credit Plans, and

(vii) setting up of a Credit Guarantee Fund Trust for Small Industries.

In order to boost investment in SSI sector, the benefits of exemptions of capital gains arising from the transfer of long term capital assets are allowed, if such capital gains are invested in the bonds issued by SIDBI.

The Government of India has come up with a comprehensive SME package which has outlined that there is a need for the banking sector to focus on credit and finance requirements of SMEs. The objective is to double the flow of credit from Rs. 67,600 crores in 2004-05 to Rs. 1, 35,000 crores to SME sector by 2009-10, i.e. within as period of five years.

As far as credits to SMEs are concerned, the concerns could be of four types viz." Timely availability of credit,

- Adequate availability of credir

- Reasonable pricing and

- Lower collateral requirements. 
When an enterxprise approaches a bank for credit, the bank focuses on the risks involved and the required risk mitigation measures. The banks are reluctant to lend to the SMEs for a number of reasons. Most prominent being the information asymmetry that arises from small businesses' lack of financial information and standardized financial statements, in addition to bank's limited knowledge about the borrower company. Due to inadequate risk perception which is on account of the fact that the strength of units do not come out clearly, pricing also gets affected and lenders prefer to be conservative and cautious

\section{Need for focused look}

In this context, there exists a need for independent party credible assessment of SME units, upon which banks can rely and base their decisions. While CIBIL has been set up to build a data base of borrowers including SME borrowers, there existed a void in compiling the information and rate the credit worthiness of SME borrowers which would enhance the comfort level of individual bankers.

\section{Smera}

As a sequel of this, an independent rating agency dedicated to the SME sector viz. the SME rating agency (SMERA) was promoted by SIDBI, Dun and Bradstreet Information Services India Private Limited, CIBIL, several public and private sector banks. Its registered office is in Mumbai. The authorized capital is Rs. 100 million with a paid up capital of Rs. 50 millions. SMERA rating is expected to not only help SMEs in getting credit from banks at favorable terms, but also, assist them in trade and commerce, both domestic and international. SMERA has since completed rating about 70 SMEs and it has entered into a Memoranda of Understanding with several banks, like Bank of India, Canara Bank, Corporation Bank, Punjab National bank, State Bank of India, Syndicate bank Union Bank of India and Vijaya Bank and several other banks to rate their SME clients. The ratings are expected to help the banks to reduce their turnaround time thus helping towards timely availability of credit. A win-win situation indeed.

The Finance Minister also delineated a 4-pronged strategy adopted by the Government of India, to promote the SME sector: 
(i) Doubling the flow of credit to the SSI and tiny sector in 5 years

(ii) Enactment of an SME bill. Currently a draft of the bill is under consideration

(iii) Launch of SMERA, a rating agency dedicated to the SME sector

(iv) Enhancement of Credit Linked Capital Subsidy (CLCS) limit from Rs.40 lakhs term loan to Rs. 100 lakhs and simultaneously enhancing the percentage of subsidy from $12 \%$ to $15 \%$, the notification of which is expected shortly.

SMERA's Rating Scale is as follows:

Figure -1.3

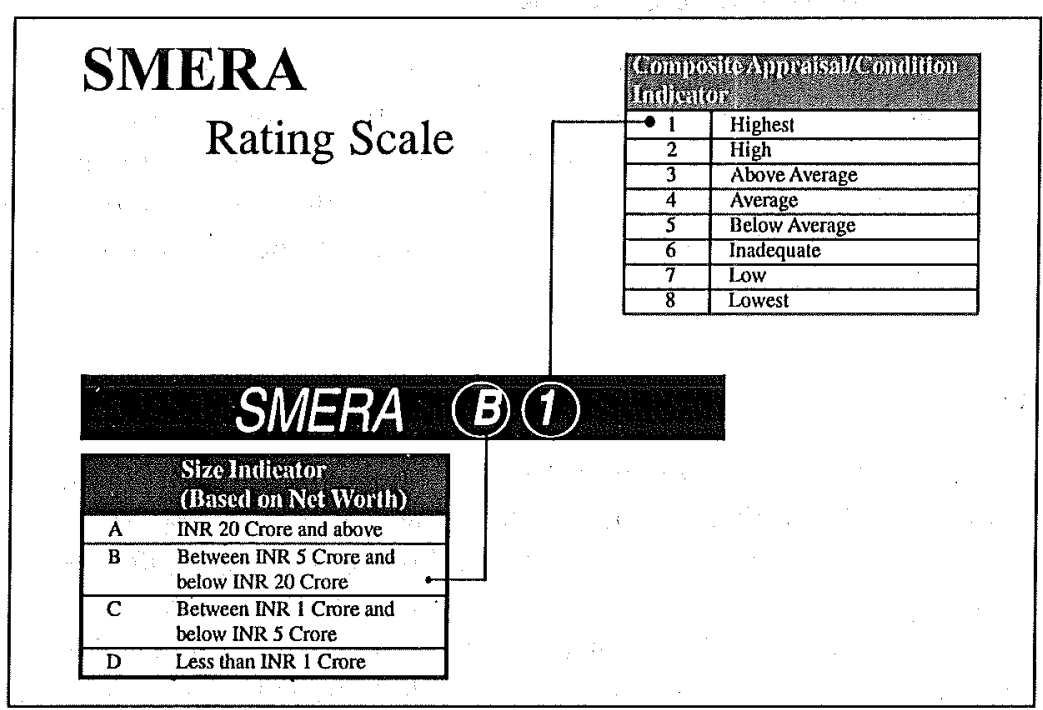

\section{Benefits of Rating}

\section{Favourable borrowing terms}

Better ratings from SMERA has already started benefiting units by way of more favourable credit terms in terms of interest rebates.

- Lower collateral requirements

- Reduced Interest Rates

- Simplified lending norms 


\section{Faster Access to Credit}

SMERA Ratings facilitate banks/lending institutions in reducing the turnaround time in processing credit applications, thereby providing SMEs access to timely and adequate credit.

\section{Lower Rating Fees}

The rating fees charged by SMERA are very competitive, and the rating fee is subsidised upto $75 \%$ for eligible SSI units. i.e. Units having a valid Small Scale Industries Registration Certificate (Permanent / Provisional).

Units can get rated as low as Rs 4209/-all taxes included.

\section{D-U-N-S NO}

number DUNS NO.

The Number is a unique nine-digit identification sequence, which provides unique identifiers of single business entities, while used by the world's most influential standards-setting organizations, it is recognized, recommended and/or required by more than $50 \mathrm{global}$, industry and trade associations

\section{Benefits to SME \& SSI Units}

- SMERA Rating adds credibility to the status of the SME unit

- It also helps opens doors to deal with large companiesesp. those who deal with a big number of vendors

- SMERA Ratings serve as motivation to adopt good governance practices which are beneficial in the long run

- SMERA Ratings also help in international trade and commerce and serve as first point to generate interest among potential trading partners

- Ratings also acts as an tool for self correction \& self improvement in event of a $0.25 \%$ interest reduction to a unit getting rated by SMERA the reduction in interest cost comes to Rs. 25000/- on a loan of Rs 1 cr for 1 year thereby outweighing the cost of rating from SMERA. 


\section{Benefit to Banks}

- SMERA Ratings facilitates Pricing of loan products / attractive terms

- It is also useful in compliance with regulatory and capital adequacy norms

- Helping the banker through Early warning signals through review ratings as mandated by it

\section{Industry-benchmarked ratings}

SMERA Ratings take into account industry dynamics by factoring in a system through which an SME could compare its strengths and weaknesses with those of other companies in the same line of business. This is done through statistically derived industry benchmarks for various ratios.

\section{Validity}

The rating certificate issued by SMERA is based on the latest financial statement available, the site visit report and management interview carried out as on a recent date.

Thus, the validity of SMERA rating of an SME unit is as on a given date and based on the assumption of a going concern.

The SME unit so rated will only get the certificate, while the bank will be pro vided with the complete report.

The SME units may visit the site www.smera.in and forward their request for rating to info@smera.in, post which they would receive an application form and checklist of documents to be submitted for availing of rating from SMERA. Alternatively, they could download the rating application form from the website and forward their request for rating together with requisite fees and the complete set of documents in duplicate as mentioned in the checklist of documents to SMERA office. 


\section{Ratings Fee Calculator}

Applicants can avail of two types of ratings

\section{i) SMERA - NSIC Credit \& Performance Ratings}

In event of the applicant possessing a valid permanent / provisional SSI certificate at the time of rating, then the following rating fees are as follows

\begin{tabular}{|c|c|c|c|c|}
\hline & \multicolumn{4}{|c|}{ Turnover } \\
\hline$N$ & Details & $<50$ LAKH & 50-200 LAKH & $>200$ LAKH \\
\hline $\begin{array}{l}e \\
\text { t }\end{array}$ & $20 \mathrm{cr}+$ & 31,120 & 26,120 & 16,120 \\
\hline w & $5 \mathrm{cr}-20 \mathrm{cr}$ & 17,090 & 12,090 & 10,523 \\
\hline$r$ & $1 \mathrm{cr}-5 \mathrm{cr}$ & 7,015 & 7,015 & 7,015 \\
\hline$h$ & Below $1 \mathrm{cr}$ & 4,209 & 4,209 & 4,209 \\
\hline
\end{tabular}

Source: www.sidbi.in

\section{ii) SMERA Ratings}

In event of a unit does not possess an valid permanent / provisional SSI certificate at the time of applying for rating then the following rating fees would be applicable

\begin{tabular}{|l|l|}
\hline \multicolumn{2}{|c|}{ Size Indicator - (Based on Net Worth) Rating Fee/Unit * } \\
\hline Less than INR I crore - Category D & Rs 16,836/- \\
\hline $\begin{array}{l}\text { Between INR I Crore \& } \\
\text { Below INR 5 Crore - Category C }\end{array}$ & Rs 28,060/- \\
\hline $\begin{array}{l}\text { Between INR 5 Crore \& below INR } \\
20 \text { Crore - Category B }\end{array}$ & Rs 42,090/- \\
\hline INR 20 Crore and above - Category A & Rs 56,120/- \\
\hline
\end{tabular}

Source: unw.sidbi.in 


\section{Rating Process Simplified}

1. SMEs may apply for SMERA rating by contacting us at our office address listed on this brochure or via email to the following address: info@smera.in. Interested parties may also contact any SIDBI office across the country.

2. A Questionnaire, seeking information on financial and qualitative factors, would be sent to the SME and would need to be filled by an authorised representative of the SME.

3. A SMERA representative will contact the SME, seeking documents and the completed questionnaire to facilitate the rating process. The representative would also conduct a site visit as part of the evaluation process.

4. Subsequent to collection of the completed application, relevant documentation and rating fees by the SMERA representative, SMERA will begin its process of evaluation.

5. SMERA shall complete the evaluation exercise and provide SMERA rating within 15 business days of receipt of all documents from the SME.

\section{Future Outlook}

\section{Factoring for the SMEs \pm a boon}

Apart from selling world class products, it is also imperative for SMEs to underpin these efforts through appropriate financing options, it is in this context that factoring offers large benefits for SMEs. Buyers and importers seem to benefit from, the intense competition among sellers in exports. They demand for a higher quality products and also finance terms that are attractive to them.

This has led to purchasing on open account terms rather than traditional payment terms like letters of credit or bank guarantees. An open account transaction is one where, the seller has agreed to give the buyer a certain tenor of credit, usually 30 to 90 days after the date of shipment. However, for the exporters, selling on the open account terms is fraught with risks, as there is a possibility of the buyer defaulting on the payment after delivery of goods.

Factoring is essentially a financial package that covers financing, credit protection, accounts receivables, book keeping and collection. 
Table showing the international factoring furnover in select Asian countries

Table 1.3

\begin{tabular}{|l|r|}
\hline \multicolumn{1}{|c|}{ Countries } & EuroMillions \\
\hline Taiwan & 8000 \\
HongKong & 2000 \\
China & 760 \\
Singapore & 400 \\
India & 175 \\
South Korea & 32 \\
Malaysia & 30 \\
Thailand & 30 \\
\hline
\end{tabular}

Source: Factors Chain International

Figure 1.4

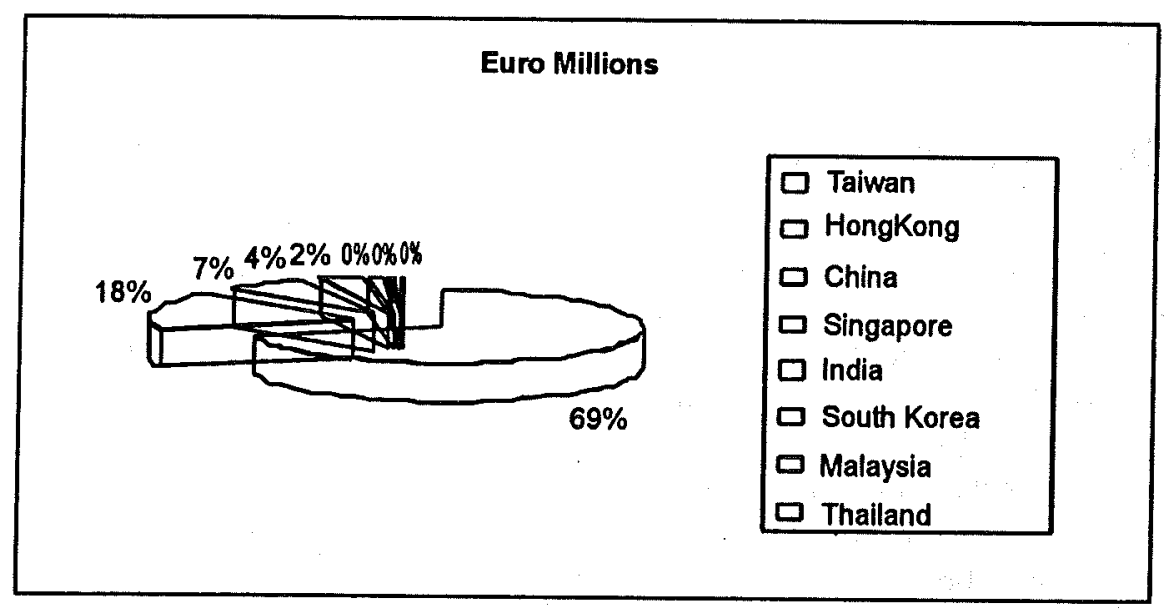




\section{Other Methods}

\section{Credit Guarantee Fund Trust for Small Industries}

A Credit Guarantee Trust (CGTSI) has been functioning towards facilitating collateral free credit to tiny enterprises. A SME fund of Rs.10,000 crore has been set up within SIDBI to channelise assistance to the SME sector at competitive rates. Government of India, in association with SIDBI, has set up a Credit Guarantee Fund Trust for Small Industries (CGTSI) to implement the guarantee scheme. The corpus of the Trust is proposed to be enhanced from the present level of Rs.7 billion to Rs. 25 billion. The main objective of the Trust is to facilitate hassle free credit to the SSI sector and encourage banks to shift from security based lending to merit based lending. SSI loans upto Rs.2.5 million are eligible to be covered under the scheme and CGTSI has so far extended guarantees to member lending institutions for around 18,000 units in the last three years of its operations, covering a loan amount of Rs.3 billion. The CGTSI contemplates to triple its business in the current year, as compared to the previous year. Some new guaranteeing techniques like mutual credit guarantee scheme on the lines of similar schemes in Italy and other European countries are also being developed.

A Credit Information Bureau (CIBIL) has been set up for the exchange of credit information between financial intermediaries.

\section{Risk Sharing Facility}

While the CGTSI extends guarantee cover for the loans upto Rs.2.5 million, there is a need for offering guarantees for loans extended by banks beyond the above limit. Under a World Bank led Project on Financing and Development of SMEs, a possibility of intro ducing a Risk Sharing Facility for the SME sector is being examined, wherein the risk in lending by banks to SMEs could be shared on paripassu basis between the originating banks and the suggested entity. Of course, the facility would be available at a cost. This mechanism, as and when in place, would mitigate the credit risks of the banks and upscale SME financing. 


\section{Venture Capital Funding}

With regard to new sources of financing, many countries are considering liberalizing the rules regarding venture capital investments. In India also, various measures have been taken in this direction. SIDBI, along with some other institutions, has taken a lead in promoting venture capital funding in the country. The Bank has contributed in setting up of 16 State level / Regional level funds; set up a National Fund for Software and IT Industry with a corpus of Rs. 1 billion and recently launched a new SME Growth Fund of Rs.1 billion corpus. This Fund would focus on units in pharma, biotech, light engineering, software and other KBIs. The SME Growth Fund corpus is contemplated to be enhanced to Rs.5 billion.

\section{Micro Credit}

Realising the potential of micro finance in stimulating economic growth, SIDBI has laid emphasis on increasing the capacity of the sector to handle credit and growth in the disbursements of micro finance. SIDBI Foundation for Micro Credit, presently functioning as a Department of SIDBI, has sanctioned an aggregate financial assistance of Rs.710 million in FY2004. The cumulative number of beneficiaries assisted under the programme in the last 4 years aggregated over 1 million, mostly women. The outstanding portfolio under the programme as at end-March 2004 is likely to be increased from a level of Rs.910 million to Rs.2 billion by the end of this year.

\section{Small and Medium Enterprises Fund}

The most important amongst the sectoral initiatives taken by the Gol and SIDBI is launching of an SME Fund of Rs. 100 billion, with a view to giving impetus to the fund flow to the SME sector. SIDBI has been advised to structure the Fund and its operations have commenced with effect from April 2004. Under the Fund, assistance is being provided to SMEs at an interest rate of 200 basis points below the Bank's PLR. Direct assistance is being extended to SMEs through SIDBI's own offices at 9.5 percent rate of interest as also by way of providing refinance to the primary lending institutions. 
Refinance to SFCs is available in the interest rate band of 7.5 percent to 8 per cent. The SME Fund provides for routing of assistance, besides SFCs, through commercial banks as well. The Fund, besides upscaling the flow of assistance to SMEs, addresses the issue of cross sector parity in the cost of loans.

\section{Setting up of a Dedicated Credit Rating Agency for SMEs}

In order to address the demand side issues of credit and provide comfort to the bank officials, initiatives have been taken to support the mechanisms of information sharing and credit rating. With a view to providing credit enhancement and comfort to the bank officials at the field level in their taking bonafide credit decisions, SIDBI has decided to launch a dedicated credit rating agency for SMEs in association with leading public sector banks. The Bank is in dialogue with select public sector banks and credit rating agencies for this purpose and the proposed entity is likely to commence its operations during the current year.

\section{Porffolio Purchase Scheme / Asset Securitisation}

With a view to widening the scope of assistance to SMEs, the process of asset securitisation offers opportunities to purchase the SME portfolio from originators and channelise funds to the sector. The portfolio so purchased can be either retained by the purchaser or sold to the investors in the capital markets through structuring of suitable instruments. SIDBI has recently been permitted by the Government of India to undertake business through asset securitisation.

\section{Debt Restructuring}

In case of debt restructuring, of SMEs the situation is typical: delayed payment of bills, obsolescence of technology, and inadequate working capital availability lack of suitable infrastructure, insufficient export credit and marketing inadequacies which lead to sluggish business and reduced revenue generation. 


\section{Cluster Based Approach}

Cluster based approach for financing SME sector offers possibilities of reduction of transaction costs and mitigation of risk. About 388 clusters have already been identified. Cluster based financing would now be treated as a thrust area. Banks will increasingly adopt the cluster based approach for SME financing. To broaden the financing options for infrastructure development in clusters through public private partnership, SIDBI will formulate a scheme in consultation with the stakeholders.

SIDBI has already initiated the process of establishing Small Enterprises Financial Centres in select clusters. Risk profile of such cluster would be studied by a professional credit rating agency and such risk profile reports would be made available to commercial banks. Each lead bank of a district will consider adoption of one cluster.

\section{Conclusion}

Inadequate funding for fast growing enterprises is generally viewed to be a major external constraint for many businesses, or so at least it is perceived. Moderating this widespread perception, in principal, the capital is there. The exercise is rather how to activate the sums of passive capital in the market, increase risk-taking culture among investors and how to raise the level of investment readiness among entrepreneurs.

"When designing and implementing innovation strategies, it is crucial for succeeding efficiently with public policy and measures, that both demand side e.g. entrepreneurs and supply side e.g. service providers or investors are addressed and equally incorporated in policy making.

"The right cultural elements combined with competitive environment and high-level of entrepreneurs seeking to accomplish or take advantage of industrial changes can provide the ability of technological economic growth through entrepreneurship.

"Policy makers should incorporate learning policies and SME training programmes so as to build thorough measures in the field. When advancing in the provision of SME programmes and services, policy makers should consider path dependency and vested interest in national measures by plugging local programmes into national efforts. 
Moreover, local programmes should keep focal points in their activity and seek collaboration with national and international counterparts.

"There is a pressing need to continue strengthening SME development through intensified international cooperation. As economies are faced with similar challenges, countries benefit mutually from bilateral and multilateral collaboration. The reorientation in developing economies calls for immediate improved North-South dialogue and international cooperation worldwide.

"In addition, the models of cooperation and learning processes must include both public and private sector actors, and the development should strongly encourage them to join forces also across borders.

\section{References:}

- SME World, Feb-Apr 2006

- SME World, May-July 2006

- Small and medium Enterprises, ICFAI University Press.

- www.laghu-udyog.com

- www.sidbi.in

- www.sbi.com

\section{Annexures}

BOX - 1: Definition of SMEs

\section{World Bank}

Micro-enterprise: up to 10 employees, total assets of up to $\$ 100,000$ and total annual sales of up to $\$ 100,000$; Small enterprise -up to 50 employees, total assets of up to $\$ 3$ million and total sales of up to $\$ 3$ million;

Medium enterprise -up to 300 employees, total assets of up to $\$ 15$ million, and total annual sales of up to $\$ 15$ million. 


\section{Albania}

Micro-enterprises: <10 employees;

Small enterprises: $10-40$ employees.

Medium-sized enterprises: 50-250 employees.

\section{Azerbaijan}

\section{Small enterprises:}

$<50$ employees in industry;

$<15$ employees in transport;

$<25$ employees in construction; and

$<10$ employees in retail trade and servicing.

\section{Medium-sized enterprises:}

51-250 employees in industry;

16-75 employees in transport;

26-150 employees in construction; and

11-50 employees in retail trade and servicing.

\section{Bulgaria}

\section{Small enterprises:}

$<50$ employees and maximum assets in balance sheet BGL 20 million.

\section{Belarus}

Small enterprises: $<200$ employees in industry with maximum annual turnover < Rbl 20 million;

$<100$ employees in innovation with maximum turnover $<$ Rbl 5 million; 


\section{Small Enterprises:}

$<100$ employees in industry and construction:

$<60$ employees in agriculture;

$<60$ employees in science;

$<50$ employees in wholesale trade;

$<30$ employees in retail trade and household services; and

$<50$ employees in other production and non-production spheres.

Medium-sized enterprises: No definition exists.

\section{Estonia}

Small enterprises: $<80$ employees and max. furnover < EEK 15 million.

\section{Tajikistan}

\section{Small enterprises:}

$<50$ employees in industry and construction;

$<15$ employees in other economic spheres.

Medium-sized enterprises: No definition exists.

\section{Ukraine:}

Small enterprises:

$<200$ employees in industry and construction;

$<50$ employees in other production spheres;

$<100$ employees in science;

$<25$ employees in non-production spheres;

$<15$ employees in retail trade.

Medium-sized enterprises: No definition exists.

Source: Compiled from UNECE (2002), 'Definition of SMEs in Countries in Transition', World Bank website, and SMI Business Directory 2002 of Malaysia. 
$<50$ employees in construction and other production spheres with maximum turnover $<$ Rbl 5 million;

$<50$ employees in catering and public services with maximum turnover $<$ Rbl 2 million;

$<25$ employees in retail trade; and $<25$ employees in other nonproduction spheres with maximum turnover $<\mathrm{Rbl} 1.5$ million.

Medium-sized enterprises: No definition exists.

\section{Hungary}

Small enterprises: 11-50 employees; maximum turnover < HUF 500 million and maximum balance sheet total < HUF 200 million.

Medium-enterprises: 51-250 employees; maximum turnover $<$ HUF 2 billion and maximum balance sheet total < HUF 1.25 billion.

Uzbekistan: Small enterprises: $<300$ employees.

Medium-sized enterprises: 300-1,000 employees.

\section{Malaysia}

Annual sales turnover no exceeding RM25 million and fulltime employees not exceeding

\section{EU}

Micro-enterprises: < 10 employees;

Small enterprises: $10-49$ employees with maximum turnover up to 7 million euros.

Medium-sized enterprises: 50-250 employees with maximum turnover up to 40 million euros.

Maximum balance sheet total is 5 million for small euros and 27 million for medium size enterprises.

\section{Latvia}

Small enterprises: $<25$ employees; max. turnover < Lats 200,000; and maximum balance sheet total < Lats 70,000. 


\section{Lithuania}

Small enterprises: $<50$ employees and maximum turnover $<$ litas 500,000 .

\section{Moldova}

Micro-enterprises: with employees $<20$;

Small enterprises: with employees between 20 and 75 persons.

Medium-sized enterprises: No definition exists.

\section{Romania}

Small enterprises: 1-20 employees and turnover between LEI 10 million and 2 billion.

Medium-sized enterprises: 21-200 employees and turnover between LEI 10 million and 2 billion.

\section{Russian Federation}

\section{Small enterprises:}

$<100$ employees in industry and construction:

$<60$ employees in agriculture;

$<60$ employees in science;

$<50$ employees in wholesale trade;

$<30$ employees in retail trade and household services; and

$<50$ employees in other production and non-production spheres.

Medium-sized enterprises: No definition exists.

\section{Estonia}

Small enterprises: < 80 employees and max. turnover < EEK 15 million. 


\section{Tajikistan}

\section{Small enterprises:}

$<50$ employees in industry and construction;

$<15$ employees in other economic spheres.

Medium-sized enterprises: No definition exists.

\section{Ukraine:}

Small enterprises:

$<200$ employees in industry and construction;

$<50$ employees in other production spheres;

$<100$ employees in science;

$<25$ employees in non-production spheres;

$<15$ employees in retail trade.

Medium-sized enterprises: No definition exists.

Source: Compiled from UNECE (2002), 3Definition of SMEs in Countries in Transition', World Bank website, and SMI Business Directory 2002 of Malaysia. 